\title{
Analysis of Thermal Expansion Coefficients of Composites \\ íReinforced with Plane-Randomly Oriented Discontinuous Carbon Fibers
}

\author{
Hogyu YoOn and Kiyohisa TAKAHASHI \\ Department of Materials Science and Engineering, Nagoya Institute of Technology, \\ Gokiso-cho, Showa-ku, Nagoya 466, Japan
}

\begin{abstract}
Thermal expansion coefficients (TEG) of composites reinforced with orientationdistributed carbon fibers have been theoretically analyzed. A solution procedure is formulated according to Eshelby's equivalent inclusion method (E.I.M.) which takes into account the orientation distribution and the interaction of fibers. A procedure based on the lamination theory (L.T.) is also developed and compared with the E.I.M. TEG are calculated for carbon fiber and glass fiber composites with several types of fiber orientation distribution. The difference between the TEC predicted by the E.I.M. and the L.T. can be attributed to an interaction between fibers in the different laminae which was not considered in L.T. While the E.I.M. is consistent for glass fiber composites, a theoretical contradiction occurs for the prediction of the TEC of composites with orientation-distributed carbon fibers, when the volume fraction of fibers approaches to $100 \%$. In a range of low fiber volume fraction, the difference between the predictions by the E.I.M. and by the L.T. is smaller for carbon fiber composites than for glass fiber composites. And the difference is small compared with errors expected in the measurements. Both of the E.I.M. and the L.T. may be used for the prediction of TEC of composites filled with orientation-distributed carbon fibers in the range of low fiber volume fraction less than about $40 \%$.
\end{abstract}

Key words: Thermal Fxpansion Coefficient / Discontinuous Carbon Fiber / PlaneRandom Orientation/Equivalent Inclusion Method/Lamination Theory

\section{平面ランダム配向非連続炭素繊維複合材の熱膨張係数の解析}

$$
\text { 尹 吴 圭・高 橋 清 久* }
$$

(原稿受理：1990年1月10日)

\section{1. 緒言}

炭素㵶維複合材は軽量で高い剛性と強度をもち, 耐疲労, 耐摩 耗性に優れ, 熱技よび電気伝導性, X線透過性がよい点から航空 宇宙機器, 自動車部品, 電気部品などに応用されている. 特に, 炭素繊維複合材は熱膨張係数が著しく小さい特長をもち, 寸法安 定性が要求される宇宙機器への用途が検討されている12,2).

複合材料の熱膨張係数は, Eshelby の等価介在物法3)を用いて 解析できる ${ }^{4), 5)}$. Takahashi et al.4) は等価介在物法を繊維の配向

* 名古屋工業大学材料工学科 $\mathbf{T} 466$ 名古屋市昭和区御器所町
分布と䋐維間相互作用を考慮でさるように拡張し, ガラス複合材 の熱膨張係数を予測した． $\left.\mathrm{Takao}^{6}\right)$ は同じく等価介在物法を用い て, 複合材の熱膨張係数に及ぼす繊維配向の乱れの影響を考察し た. しかし，複合材料の熱膨張係数に関するこれらの理論的研究

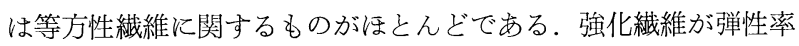
抢よび熱膨張係数に異方性をるつ場合に関する理論も報告されて いるが5),7) 9), 繊維が一軸配向している複合材に限られる.

複合材料の熱膨張係数は積層理論を用いても解析できる. 積層 理論を用いて, Craft and Christensen ${ }^{10)}$ は等方性複合材料の 2 次元括よび 3 次元的熱膨張係数を予測し, Uemura et al. ${ }^{11)}$ は斜 交積層板の熱膨張係数及び残留応力を積層角の関数として導出し 
た.

等価介在物法を用いた熱膨張係数の理論的研究では，炭素絨維 が配向分布している場合には矛盾が生じることが知られている ${ }^{12)}$. これは炭素㵶維の非常に大きい異方性のためと考兄られるが，ぞ の程度の誤差があるかを考察した報告はない，そこで，本報告で は異方性の繊維が配向分布している場合の複合材の熱膨張係数を， Eshelby の等価介在物法扣よび積層理論を用いて解析し，比較検 討する.

本報告の解析は非連続炭素㵶維複合材にも適用することを目的 とする. 種々の方向に配向した短䋐維マットに樹脂を含浸した複

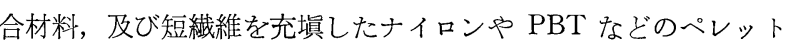
を射出，または押し出し成形する場合がこれに相当する，このた め絨維形状を回転棈円体で近似し, 強化繊維のアスペクト比, 弾 性率と熱膨張係数の異方性，配向分布招よび䋐維間相互作用を考 虑に入れた等価介在物法による計算手順を一般的な形に定式化す る. 比較のため積層理論による解析法も示す. 数值計算では炭素 䋐維を横等方性と仮定し，一軸配向，斜交積層板，西面ランダム および平面内での配向の乱れの影響を検討する，最後に，配向分 布している炭素繊維複合材料の熱膨張係数を予測するための，等 価介在物法と積層理論の適用可能性について考察する。

\section{2. 解 析}

\section{$2 \cdot 1$ 等価介在物法}

本節の熱膨張係数解析では，繊維の配向分布と絨維間相互作用 を考慮に入れた Takahashi et al.4) の解析を基礎とし，緎維の異 方性も考虑する。まず，等価介在物法について簡単に説明する。

無限大等方等質物体 $D$ 中の一つの領域 $V$ (これを等価介在物と 呼ぶ）に，応力を伴わない eigen 歪 $\dot{e}_{\mathrm{ij}}$ *が生じる場合を考觉る。 $V$ はそのまわりの領域（ $D-V$ ，これをマトリックスと呼ぶ）に よって自由な変形が拘束され, 拘束歪 $\dot{e}_{\mathrm{ij}} \mathrm{c}$ が発生する. 領域 $V$ を Fig. 1 (a) のよう楕円体と仮定すると， $\dot{e}_{i \mathrm{j}}^{\mathrm{c}}$ はV 中の位置によ らず一定となり次式で与えられる゙2.

$$
\dot{e}_{\mathrm{ij}} \mathrm{c}=T_{\mathrm{ijk} 1} \dot{e}_{\mathrm{k} 1} *
$$

ここで, $T_{\mathrm{ijk} 1}$ は Eshelby のテンソルと呼ばれ，強化繊維のア スペクト比 $\rho=c / a$ (Fig. 1 (a) 参照) とマトリックスのポアソン

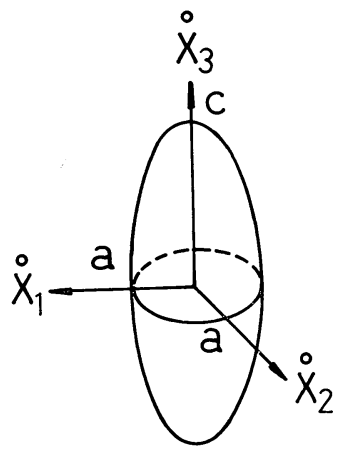

(a)

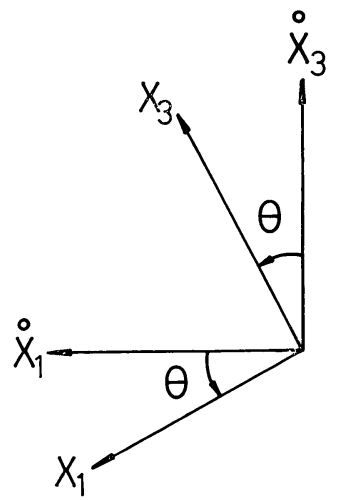

( b )
Fig. 1 (a) Ellipsoidal inclusion. (b) Transformation of coordinates.
比によって決まる定数である (付録参照). 以上は無限大マトり ックス中に 1 個の等価介在物が存在する場合であるが，有限の大 きさをもつ物体中に多数の等価介在物が存在する場合は，自由表 面の存在と介在物間相互作用によって付加的な弾性歪 $\dot{e}_{\mathrm{ij}} \mathrm{m}$ が発 生する。

以上の関係を複合材の熱膨張係数の計算に適用する。強化繊維 の熱膨張係数 $\alpha_{\mathrm{ij}}{ }^{*}$ ，マトリックスのそれを $\alpha$ と，弾性率をそれ ぞれ $C^{*}{ }_{\mathrm{pqij}}, C_{\mathrm{pqij}}$ とする。 まず，等価介在物（弾性率，熱膨張 係数はマトリックスと等しく, eigen 歪 $\dot{e}_{\mathrm{ij}}{ }^{*}$ をむつ)について考 える．等価介在物の全歪は $\dot{e}_{\mathrm{ij}}{ }^{*}$ に起因する歪 $\left(\dot{e}_{\mathrm{ij}}^{\mathrm{c}}+\dot{e}_{\mathrm{ij}} \mathrm{m}\right)$ と温度 上昇による熱膨張 $\alpha \Delta T \delta_{i \mathrm{j}}$ の和となっている．ここで， $\Delta T$ は温 度変化， $\delta_{\mathrm{ij}}$ はクロネッカーのデルタである。 このうち, 弾性歪 は $\left(\dot{e}_{\mathrm{ij}}^{\mathrm{c}}+\dot{e}_{\mathrm{ij}}{ }^{\mathrm{m}}-\dot{e}_{\mathrm{ij}}{ }^{*}\right)$ であり, 応力 $\sigma_{\mathrm{pq}}$ は $C_{\mathrm{pq} \mathrm{ij}}\left(\dot{e}_{\mathrm{ij}}{ }^{\mathrm{c}}+\dot{e}_{\mathrm{ij}} \mathrm{m}^{\mathrm{m}}-\dot{e}_{\mathrm{ij}}{ }^{*}\right)$ である。

実際の強化繊維がこれと全く同じ応力と歪をもつならば，マト リックスとの界面に掠ける応力と変位の連続性を保ったまま，等 価介在物と実際の強化繊維との置き換兄が可能である。実際の強 化繊維の全歪を等価介在物の全歪 $\left(\dot{e}_{\mathrm{ij}} \mathrm{c}+\dot{e}_{\mathrm{ij}} \mathrm{m}+\alpha \Delta T \delta_{\mathrm{i}_{\mathrm{j}}}\right)$ と等乙 く扔く，このとき，実際の強化䋐維の弾性歪は $\left(\dot{e}_{i \mathrm{j}} \mathrm{c}+\dot{e}_{\mathrm{ij}} \mathrm{m}+\right.$ $\left.\alpha \Delta T \delta_{\mathrm{ij}}-\alpha_{\mathrm{ij}}{ }^{*} \Delta T \delta_{\mathrm{ij}}\right)$ であり, 応力は $C^{*}{ }_{\mathrm{pqij}}\left\{\dot{e}_{1 \mathrm{j}}{ }^{\mathrm{c}}+\dot{e}_{\mathrm{ij}} \mathrm{m}-\left(\alpha_{\mathrm{ij}}{ }^{*}\right.\right.$ a) $\left.\Delta T \delta_{\mathrm{ij}}\right\}$ となる. したがって，

$$
\begin{aligned}
& C_{\mathrm{pq} \mathrm{ij}}\left(\dot{e}_{\mathrm{ij}}^{\mathrm{c}}+\dot{e}_{\mathrm{ij}}^{\mathrm{m}}-\dot{e}_{\mathrm{ij}}{ }^{*}\right) \\
& \quad=C^{*}{ }_{\mathrm{pq} \mathrm{ij}}\left\{\dot{e}_{\mathrm{ij}}{ }^{\mathrm{c}}+\dot{e}_{\mathrm{ij}} \mathrm{m}-\left(\alpha_{\mathrm{ij}}{ }^{*}-\alpha\right) \Delta T \delta_{\mathrm{ij}}\right\}
\end{aligned}
$$

が成り立てば，実際の強化繊維と等価介在物との置き換えが可能 となる. 歪 $e_{\mathrm{ij}}$ 上の丸印は強化繊維の主軸と平行に設定した座標 系に扮将る歪であることを示す。

強化緘維を等価介在物で置き換えた均質物体では， $\Delta T$ の温度 上升によって $\alpha \Delta T \delta_{\mathrm{ij}}$ だけ膨張し，さらに等価介在物の eigen 歪 $\dot{e}_{i \mathrm{i}}{ }^{*}$ とよって物体全体として $V_{\mathrm{f}}\left\langle e_{\mathrm{ii}}{ }^{*}\right\rangle$ だけ歪む. ここで， $V_{\mathrm{f}}$ は強 化繊維の体積分率である。実際の複合材料は温度変化 $\Delta T$ によっ てこれと全く同じ変形を示すことになり，見かけの熱膨張係数 $\alpha_{\mathrm{ij}}{ }^{* *}$ は

$$
\alpha_{\mathrm{ij}}{ }^{* *}=\alpha \delta_{\mathrm{ij}}+V_{\mathrm{f}}\left\langle e_{\mathrm{ij}}{ }^{*}\right\rangle / \Delta T
$$

で与兄られる．ここで， $e_{\mathrm{ij}}$ * は式(2)の解 $\dot{e}_{\mathrm{ij}}{ }^{*}$ を試料中に固定した 座標系 $\left(x_{1}, x_{2}, x_{3}\right)$ (Fig. 1 (b)) 飞変換した歪を表し，〈〉は 試料中のすべての介在物に関する平均を意味する。

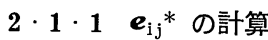

以下の記述では, 歪と応力を 6 行 1 列のベクトルで表示する 強化䋐維の主軸と平行に設定した座標系 $\left(\stackrel{\circ}{x}_{1}, \stackrel{\circ}{x}_{2}, \stackrel{x}{x}_{3}\right)$ と, 試料中 に固定した座標系 $\left(x_{1}, x_{2}, x_{3}\right)$ との関係を, Fig. 1 (b) を参照し て次式で定義する。

$$
\left.\begin{array}{l}
x_{1}=\check{x}_{1} \cos \theta-\check{x}_{3} \sin \theta \\
x_{2}=\dot{x}_{2} \\
x_{3}=\check{x}_{1} \sin \theta+\check{x}_{3} \cos \theta
\end{array}\right\}
$$

この関係より, 歪の座標変換マトリックス $X_{\mathrm{ij}}$ 扣よび $Y_{\mathrm{i} j}$

$$
\left.\begin{array}{l}
\dot{e}_{\mathrm{i}}=X_{\mathrm{ij}} e_{\mathrm{j}} \\
e_{\mathrm{i}}=Y_{\mathrm{ij}} \dot{e}_{\mathrm{j}}
\end{array}\right\} \quad(i, j=1 \sim 6)
$$


は次式で与えられる.

$$
X_{\mathrm{ij}}=\left(\begin{array}{cccccc}
\cos ^{2} \theta & 0 & \sin ^{2} \theta & 0 & 2 \sin \theta \cos \theta & 0 \\
0 & 1 & 0 & 0 & 0 & 0 \\
\sin ^{2} \theta & 0 & \cos ^{2} \theta & 0 & -2 \sin \theta \cos \theta & 0 \\
0 & 0 & 0 & \cos \theta & 0 & -\sin \theta \\
-\sin \theta \cos \theta & 0 & \sin \theta \cos \theta & 0 & \cos ^{2} \theta-\sin ^{2} \theta & 0 \\
0 & 0 & 0 & \sin \theta & 0 & \cos \theta
\end{array}\right)
$$

$$
Y_{\mathrm{ij}}=\left(\begin{array}{cccccc}
\cos ^{2} \theta & 0 & \sin ^{2} \theta & 0 & -2 \sin \theta \cos \theta & 0 \\
0 & 1 & 0 & 0 & 0 & 0 \\
\sin ^{2} \theta & 0 & \cos ^{2} \theta & 0 & 2 \sin \theta \cos \theta & 0 \\
0 & 0 & 0 & \cos \theta & 0 & \sin \theta \\
\sin \theta \cos \theta & 0 & -\sin \theta \cos \theta & 0 & \cos ^{2} \theta-\sin ^{2} \theta & 0 \\
0 & 0 & 0 & -\sin \theta & 0 & \cos \theta
\end{array}\right)
$$

式(1)を式(2)に代入して $\dot{e}_{\mathrm{ij}}$ *について解く，その解を $(6 \times 1)$ の ベクトルで表示すると，

$$
\dot{e}_{\mathrm{i}}{ }^{*}=D_{\mathrm{ij}} \dot{e}_{\mathrm{i}}^{\mathrm{m}}-E_{\mathrm{ij}} Q_{\mathrm{j}} \Delta T
$$

と表すことができる。ここで，

$$
\left.\begin{array}{ll}
Q_{\mathrm{j}}=C_{\mathrm{jk}} *\left(\alpha_{\mathrm{k}} *-\alpha\right) & i=1 \sim 3 \\
Q_{\mathrm{j}}=0 & j=4 \sim 6
\end{array}\right\}
$$

と招いた，式(9)を，式(6)を用いて試料中に固定した座標系に変換 すると,

$$
e_{\mathrm{i}}^{*}=H_{\mathrm{ij}} e_{\mathrm{j}}^{\mathrm{m}}-H_{\mathrm{ij}}^{\prime} Q_{\mathrm{j}} \Delta T
$$

を得る。ここで,

$$
H_{\mathrm{ij}}=Y_{\mathrm{ik}} D_{\mathrm{k} 1} X_{1 \mathrm{j}}, \quad H^{\prime}{ }_{\mathrm{ij}}=Y_{\mathrm{ik}} E_{\mathrm{kj}}
$$

である。

一方，式(1)は座標変換により

$$
e_{\mathrm{i}}^{\mathrm{c}}=M_{\mathrm{ij}} e_{\mathrm{j}}^{\mathrm{m}}-M_{\mathrm{ij}}^{\prime} Q_{\mathrm{j}} \Delta T
$$

と表すことができる。ここで，

$$
M_{\mathrm{ij}}=Y_{\mathrm{ik}} T_{\mathrm{k} 1} D_{1 \mathrm{~m}} X_{\mathrm{mj}}, \quad M_{\mathrm{ij}}^{\prime}=Y_{\mathrm{ik}} T_{\mathrm{k} 1} E_{1 \mathrm{j}}
$$

である.

$e_{\mathrm{i}}{ }^{*}$ および $e_{\mathrm{i}}^{\mathrm{c}}$ を求めるとき使万行列 $H_{\mathrm{ij}}, M_{\mathrm{ij}}$ 㧊よび $H^{\prime}{ }_{\mathrm{ij}}, M^{\prime}{ }_{\mathrm{i} j}$ は充填材の配向角 $\theta$ の関数となって括り, 充媜材が配向分布して いる場合には, $H_{\mathrm{ij}}, M_{\mathrm{ij}}, H^{\prime}{ }_{\mathrm{ij}}$ 扤よび $M^{\prime}{ }_{\mathrm{ij}}$ を全ての充填材に関 して平均した $\left\langle H_{\mathrm{ij}}\right\rangle$ 和よび $\left\langle M_{\mathrm{ij}}\right\rangle$ 等を式(11), (13)に代入して $\left\langle e_{\mathrm{ij}}{ }^{*}\right\rangle$ および $\left\langle e_{\mathrm{ij}} \mathrm{c}\right\rangle$ を計算する. 平均值 $\left\langle H_{\mathrm{ij}}\right\rangle$ 扔よび $\left\langle M_{\mathrm{ij}}\right\rangle$ 等は, 例兄 ば充填材が $-\beta \leqq \theta \leqq \beta$ の範囲で一様分布している場合，

$$
\begin{aligned}
& \left\langle H_{\mathrm{ij}}\right\rangle=\frac{1}{2 \beta} \int_{-\beta}^{\beta} H_{\mathrm{ij}}(\theta) \mathrm{d} \theta \\
& \left\langle M_{\mathrm{ij}}\right\rangle=\frac{1}{2 \beta} \int_{-\beta}^{\beta} M_{\mathrm{ij}}(\theta) \mathrm{d} \theta
\end{aligned}
$$

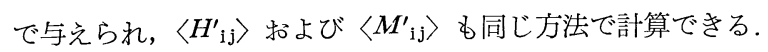

\section{$\mathbf{2} \cdot \mathbf{1} \cdot \mathbf{2} \boldsymbol{e}_{\mathrm{i}}^{\mathrm{m}}$ の計算}

ここまでの計算では， $e_{\mathrm{i}}^{\mathrm{m}}$ は未知数のまま残っている.この $e_{\mathrm{i}}^{\mathrm{m}}$ を試料中の場所によらず一様と仮定すると, 均質物体では内 部応力場だけによって生ずる弾性丕の平均值は，ゼロであること から次式が成り立つ。

$$
\left(1-V_{\mathrm{f}}\right) e_{\mathrm{i}}{ }^{\mathrm{m}}+V_{\mathrm{f}}\left(e_{\mathrm{i}}^{\mathrm{m}}+\left\langle e_{\mathrm{i}}^{\mathrm{c}}\right\rangle-\left\langle e_{\mathrm{i}}^{*}\right\rangle\right)=0
$$

この式から

$$
e_{\mathrm{i}}^{\mathrm{m}}=-V_{\mathrm{f}}\left(\left\langle e_{\mathrm{i}}^{\mathrm{c}}\right\rangle-\left\langle e_{\mathrm{i}}^{*}\right\rangle\right)
$$

を得る。式(11)，(13)の平均值を(18)に代入すると，

$$
\begin{aligned}
e_{\mathrm{i}}^{\mathrm{m}}= & -V_{\mathrm{f}}\left\{\left(\left\langle M_{\mathrm{ij}}\right\rangle-\left\langle H_{\mathrm{ij}}\right\rangle\right) e_{\mathrm{j}}^{\mathrm{m}}\right. \\
& \left.-\left(\left\langle M^{\prime}{ }_{\mathrm{ij}}\right\rangle-\left\langle H^{\prime}{ }_{\mathrm{ij}}\right\rangle\right) Q_{\mathrm{j}} \Delta T\right\}
\end{aligned}
$$

となり，ここでそれぞれ

$$
\left.\begin{array}{l}
\left\langle M_{\mathrm{ij}}\right\rangle-\left\langle H_{\mathrm{ij}}\right\rangle=\left\langle N_{\mathrm{ij}}\right\rangle \\
\left\langle M^{\prime}{ }_{\mathrm{ij}}\right\rangle-\left\langle H^{\prime}{ }_{\mathrm{i}}\right\rangle=\left\langle N^{\prime}{ }_{\mathrm{ij}}\right\rangle
\end{array}\right\}
$$

と打くと，

$$
e_{\mathrm{i}}^{\mathrm{m}}=-V_{\mathrm{f}}\left(\left\langle N_{\mathrm{ij}}\right\rangle e_{\mathrm{j}}^{\mathrm{m}}-\left\langle N^{\prime}{ }_{\mathrm{ij}}\right\rangle Q_{\mathrm{j}} \Delta T\right)
$$

を得る。ここで,

$$
\delta_{\mathrm{ij}}+V_{\mathrm{f}}\left\langle N_{\mathrm{ij}}\right\rangle=\left\langle P_{\mathrm{ij}}\right\rangle
$$

と叔くと，式(21)は

$$
\left\langle P_{\mathrm{ij}}\right\rangle e_{\mathrm{j}}^{\mathrm{m}}=V_{\mathrm{f}}\left\langle N_{\mathrm{ij}}^{\prime}\right\rangle Q_{\mathrm{j}} \Delta T
$$

となり，結局

$$
e_{\mathrm{i}}^{\mathrm{m}}=V_{\mathrm{f}}\left\langle P_{\mathrm{ij}}\right\rangle^{-1}\left\langle N^{\prime}{ }_{\mathrm{jk}}\right\rangle Q_{\mathrm{k}} \Delta T
$$

を得る。この解を式(11)に代入して $e_{\mathrm{ij}}$ *を求め, その平均值〈 $\left.e_{\mathrm{ij}}{ }^{*}\right\rangle$ を式(3)に代入すると, 最終的に複合材料の熱膨張係数 $\alpha_{\mathrm{ij}}$ ** が求 められる。

\section{$2 \cdot 2$ 積層理論}

積層板を構成する各層（一方向炭素繊維複合材）は見かけ上横 等方性であり, 平面応力状態での歪一応力関係は次のように示さ れる.

$$
\left(\begin{array}{c}
\varepsilon_{1} \\
\varepsilon_{2} \\
\gamma_{12}
\end{array}\right)=\left(\begin{array}{ccc}
S_{11} & S_{12} & 0 \\
S_{12} & S_{22} & 0 \\
0 & 0 & S_{66}
\end{array}\right)\left(\begin{array}{c}
\sigma_{1} \\
\sigma_{2} \\
\tau_{12}
\end{array}\right)
$$

ここで, $S_{\mathrm{ij}}$ はコンプライアンスであり, 次式で与えられる.

$$
\begin{aligned}
& S_{11}=\frac{1}{E_{1}} \quad S_{22}=\frac{1}{E_{2}} \\
& S_{12}=-\frac{\nu_{12}}{E_{1}}=-\frac{\nu_{21}}{E_{2}} \\
& S_{66}=\frac{1}{G_{12}}
\end{aligned}
$$

式(25)の歪-応力関係を応力について解くと，

$$
\left(\begin{array}{c}
\sigma_{1} \\
\sigma_{2} \\
\tau_{12}
\end{array}\right)=\left(\begin{array}{ccc}
Q_{11} & Q_{12} & 0 \\
Q_{12} & Q_{22} & 0 \\
0 & 0 & Q_{66}
\end{array}\right)\left(\begin{array}{c}
\varepsilon_{1} \\
\varepsilon_{2} \\
\gamma_{12}
\end{array}\right)
$$

となる。㵶維の主軸が試料中に固定した座標と傾いているとき，

$$
\left(\begin{array}{c}
\sigma_{\mathrm{x}} \\
\sigma_{\mathrm{y}} \\
\tau_{\mathrm{xy}}
\end{array}\right)=\left(\begin{array}{lll}
\bar{Q}_{11} & \bar{Q}_{12} & \bar{Q}_{16} \\
\bar{Q}_{12} & \bar{Q}_{22} & \bar{Q}_{26} \\
\bar{Q}_{16} & \bar{Q}_{26} & \bar{Q}_{66}
\end{array}\right)\left(\begin{array}{c}
\varepsilon_{\mathrm{x}} \\
\varepsilon_{\mathrm{y}} \\
\gamma_{\mathrm{xy}}
\end{array}\right)
$$

となる.ここで, $\bar{Q}_{\mathrm{ij}}$ は transformed reduced stiffness であり， 種々の文献 ${ }^{13)},{ }^{14}$ に記述されている.

一方, 温度変化をもつ場合の応力-歪関係は,

$$
\left(\begin{array}{c}
\sigma_{\mathrm{x}} \\
\sigma_{\mathrm{y}} \\
\tau_{\mathrm{xy}}
\end{array}\right)=\left[\bar{Q}_{\mathrm{ij}}\right]\left(\begin{array}{ll}
\varepsilon_{\mathrm{x}} & -\alpha_{\mathrm{x}} \Delta T \\
\varepsilon_{\mathrm{y}} & -\alpha_{\mathrm{y}} \Delta T \\
\gamma_{\mathrm{xy}} & -\alpha_{\mathrm{xy}} \Delta T
\end{array}\right)
$$


で与えられ， $N$ 層の一方向 CFRP を中央面に関して対称に貼り 合わせた場合の熱膨張係数は，式(29)を厚さ方向に積分した合力か ら得られる。刘称積層板のそりはゼロであり, 合力 $N_{\mathrm{i}}$ は

$$
\begin{aligned}
\left(\begin{array}{c}
N_{\mathrm{x}} \\
N_{\mathrm{y}} \\
N_{\mathrm{xy}}
\end{array}\right)= & \int\left[\bar{Q}_{\mathrm{ij}}\right]_{\mathrm{k}}\left(\begin{array}{ccc}
\varepsilon_{\mathrm{x}} & - & \alpha_{\mathrm{x}} \Delta T \\
\varepsilon_{\mathrm{y}} & - & \alpha_{\mathrm{y}} \Delta T \\
\gamma_{\mathrm{x} y} & - & \alpha_{\mathrm{xy}} \Delta T
\end{array}\right)_{\mathrm{k}} \mathrm{d} z \\
= & {\left[A_{\mathrm{i} j}\right]\left(\begin{array}{c}
\varepsilon_{\mathrm{x}} \\
\varepsilon_{\mathrm{y}} \\
\gamma_{\mathrm{xy}}
\end{array}\right) } \\
& -\sum_{\mathrm{k}=1}^{\mathrm{N}}\left[\bar{Q}_{\mathrm{ij} j}\right]_{\mathrm{k}}\left(\begin{array}{c}
\alpha_{\mathrm{x}} \\
\alpha_{\mathrm{y}} \\
\alpha_{\mathrm{xy}}
\end{array}\right)_{\mathrm{k}} \Delta T\left(z_{\mathrm{k}}-z_{\mathrm{k}-1}\right)
\end{aligned}
$$

で与兄られる。ここで， $A_{\mathrm{ij}}$ は $\bar{Q}_{\mathrm{ij}}$ を厚さ方向に積分した extensional stiffness, $z_{\mathrm{k}}$ は中央面からの距離であり, 添字 $k$ は $k$ 番目 の層を表す。

対称積層板の歪は中央面の歪で代表され，合力はゼロになるこ とから,

$$
\left(\begin{array}{c}
\varepsilon_{\mathrm{x}} \\
\varepsilon_{\mathrm{y}} \\
\gamma_{\mathrm{xy}}
\end{array}\right)=\left[A_{\mathrm{ij}}\right]^{-1} \sum_{\mathrm{k}=1}^{\mathrm{N}}\left[\bar{Q}_{\mathrm{ij}}\right]_{\mathrm{k}}\left(\begin{array}{c}
\alpha_{\mathrm{x}} \\
\alpha_{\mathrm{y}} \\
\alpha_{\mathrm{xy}}
\end{array}\right)_{\mathrm{k}} \Delta T\left(z_{\mathrm{k}}-z_{\mathrm{k}-1}\right)
$$

と表現できる，この歪が積層板の熱膨張係数を表す，

\section{3. 数値計算例}

$3 \cdot 1$ 一方向複合材料

䋐維が一軸配向している場合の等価介在物法による数值計算結

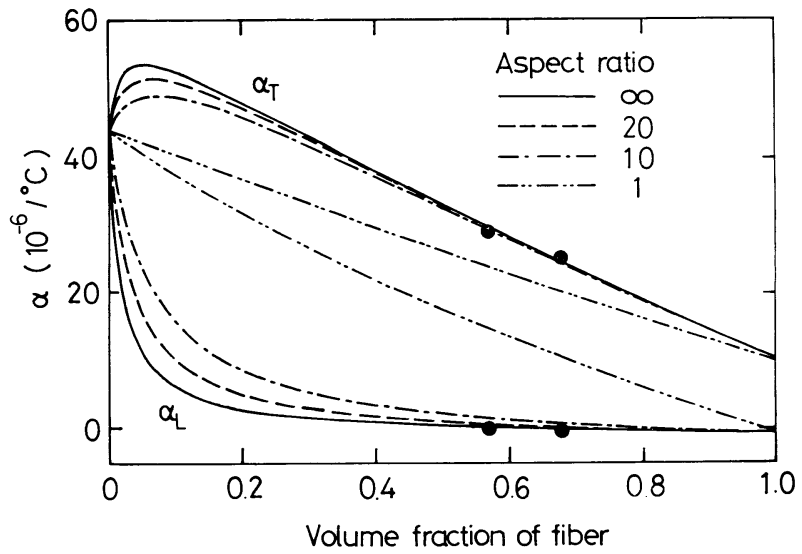

Fig. 2 Thermal expansion coefficient of unidirectional carbon fiber composite as a function of volume fraction of carbon fiber. - : experimental data by Bowles ${ }^{15)}$.

Table I. Properties of constituents.

\begin{tabular}{cccccccc}
\hline & $\begin{array}{c}\text { Young's } \\
\text { modulus } \\
(\mathrm{GPa})\end{array}$ & $\begin{array}{c}\text { Shear } \\
\text { modulus } \\
(\mathrm{GPa})\end{array}$ & $\begin{array}{c}\text { Poisson's } \\
\text { ratio }\end{array}$ & $\begin{array}{c}\text { Thermal expansion } \\
\text { coefficient } \\
\left(10^{-6} /{ }^{\circ} \mathrm{C}\right)\end{array}$ \\
\hline & $E_{\mathrm{L}}$ & $E_{\mathrm{T}}$ & $G_{\mathrm{LTT}}$ & $\nu_{\mathrm{LT}}$ & $\nu_{\mathrm{TT}}$ & $\alpha_{\mathrm{L}}$ & $\alpha_{\mathrm{T}}$ \\
\hline $\begin{array}{c}\text { carbon } \\
\text { fiber } \\
\text { epoxy }\end{array}$ & 233 & 23 & 9 & 0.2 & 0.4 & -0.54 & 10.08 \\
\hline
\end{tabular}

果をFig. 2 に示す. ただし, 計算に用いた定数特よび実験デー タは Bowles ${ }^{15)}$ から引用し, Table I そ示した。

アスペクト比が無限大のとき, 繊維方向の熱膨張係数 $\left(\alpha_{\mathrm{L}}\right)$ は 繊維方向の高い弾性率の影響を大きく受け，体積分率が40\%以上 になると，繊維自体の熱膨張係数とほぼ等しくなり，著しく低い 值を示す．さらに，体積分率が60\%以上になると，アスペクト比 が20以上の場合, 熱膨張係数はアスペクト比に依らずほぼ等しい 值を示す．図中の黒丸は Bowles ${ }^{15)}$ の実験データであり，アスペ クト比無限大の計算值とほぼ一致している。

以下の積層理論で用いる単層板 (一方向 CFRP) の熱膨張係数 と弾性率は等価介在物法から求めた。

\section{$3 \cdot 2$ 斜交積層板 ${ }^{11), 16}$}

積層板表面が $x y$ 面に平行であり, 積層角が $x$ 軸に対して $\pm \theta$ の斜交積層板 (Fig. 3 参照) に関して， $x$ 方向の熱膨張係数を 積層角 $\theta$ の関数として Fig. 4 亿表す。ただし，計算に用いた定 数掞よび実験データは，参考文献11)を参照されたい。

積層理論から求めた熱膨張係数は積層角全範囲にわたって実験 データと良く一致しているが，等価介在物法では同一のラミナの

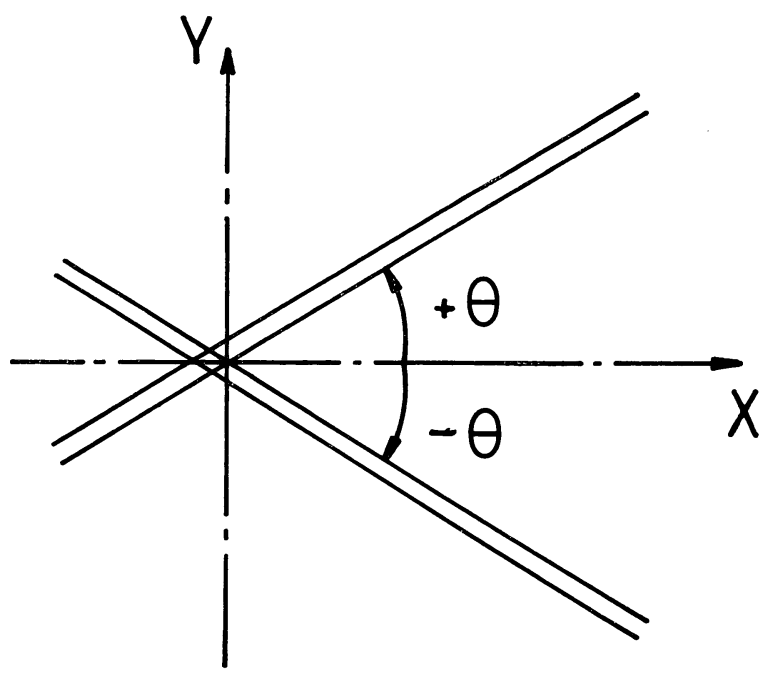

Fig. 3 The angle-ply laminate and the definition of fiber orientation $\theta$. The $\pm \theta$ laminae are stacked parallel to the $x y$ plane.

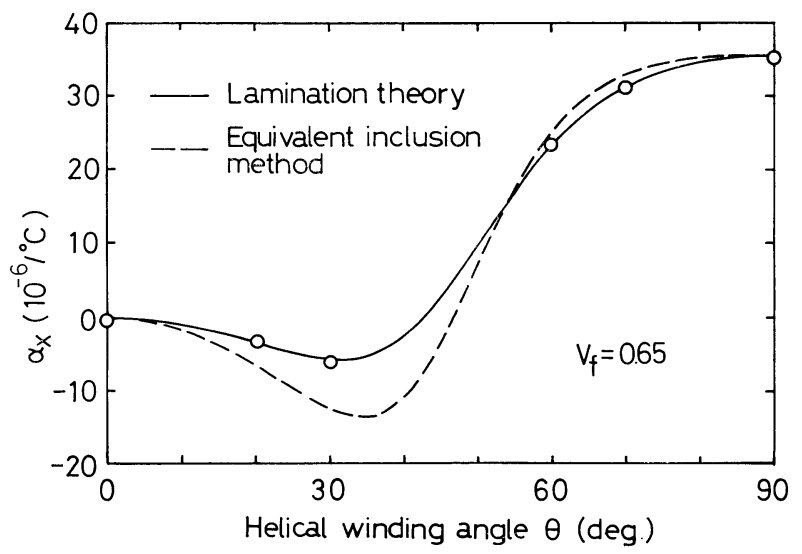

Fig. 4 Thermal expansion coefficients, $\alpha_{\mathrm{x}}$, in a angle ply laminate as a function of helical winding angle $\theta . \bigcirc$ : experimental data ${ }^{11}$. 
中に+ $\theta$ と一 $\theta$ の層が含まれていると考えて和り, 斜交積層板の 実験データとはあまり良い一致はみられない。しかし, 両方共に ほぼ同様の傾向を示して招り, 特に $\theta=10 \sim 40^{\circ}$ で負の值を示し ていることに注意されたい，これは瀻維自体の繊維軸方向の熱膨 張係数が負であり，瀻維が大きな異方性をもつためと考光られる.

\section{$3 \cdot 3$ 平面ランダム配向}

Fig. 5，6 は，それぞれ積層理論及び等価介在物法から求めた 平面ランダム配向積層板の熱膨張係数である．体積分率の增加に よって熱膨張係数は減少している.アスペクト比 1 の場合を除い て，体積分率が高くなると，緎維自体の繊維軸方向の熱膨張係数 に近い值を示している。これは横方向に比べ䋐維軸方向の弾性率

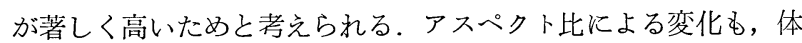
積分率によって異なるが，ある程度のアスペクト比を越えると熱 膨張係数はほぼ一定となる。しかし，等価介在物法から求めた熱

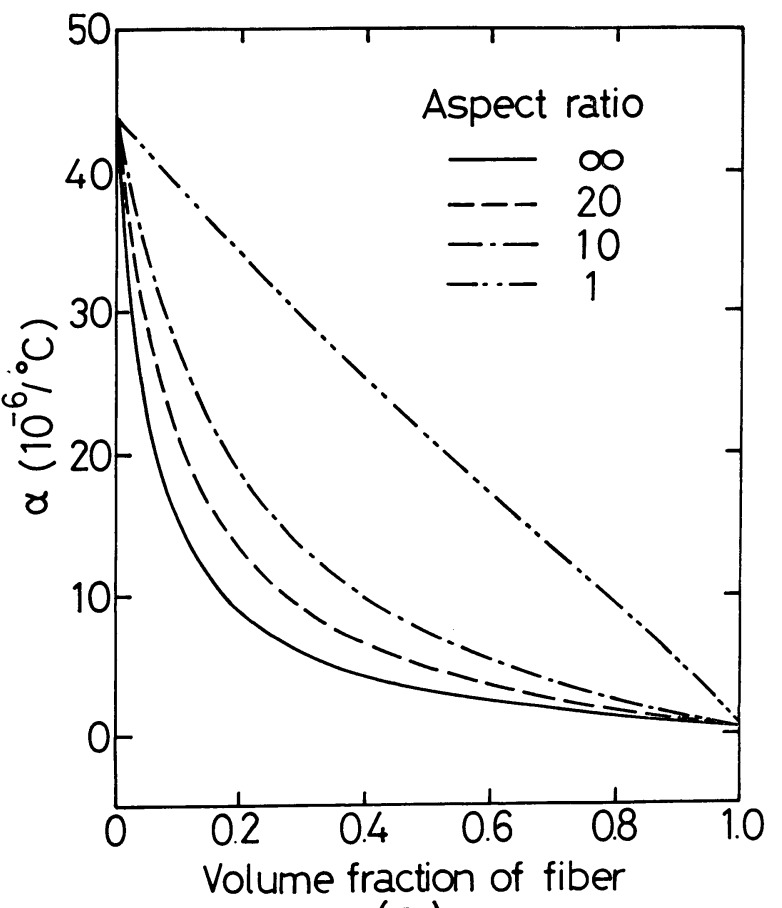

(a)

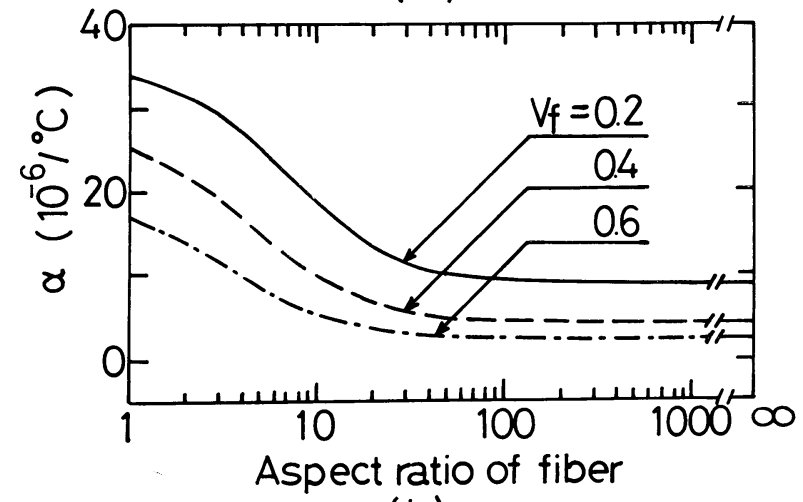

(b)

Fig. 5 Thermal expansion coefficient of composite in which carbon fibers are plane-randomly oriented predicted by lamination thery : (a) as a function of volume fraction of fiber; (b) as a function of aspect ratio of fiber.
膨張係数（Fig. 6) は，体積分率の增加とともに積層理論による 值と段々差がでてきて， $V_{\mathrm{f}}=100 \%$ では球の場合高い值を, 䋐維 の場合は低い值を示す．特に， $V_{\mathrm{f}}=80 \%$ 以上では䋐維自体の熱 膨張係数 $\left(-0.54 \times 10^{-6} /{ }^{\circ} \mathrm{C}\right)$ より低い值が現れている。これが 等価介在物法を，炭素纎維が配向分布をるつ場合に適用するとき の矛盾であり，適用限界は体積分率に依存すると考穴られる。

次に, 繊維の方向が Fig. 7 (a) のよ5に $-\beta \leqq \theta \leqq \beta$ の間に分 布して括り，さらにこの分布がー $\beta$ から+ $\beta$ にわたって Fig. 7 (b) のよ5に一定である場合を考える，短繊維複合材を射出また は押し出し成形する場合，このような瀻維配向の乱れが考兄られ る. この場合, 分布限界 $\beta$ の関数として, 炭素絨維複合材の熱膨 張係数を積層理論を用いて Fig. 8 亿示す. Fig. 4 の斜交積層板 でも述べたように，x 方向 (Fig. 3,7参照) の熱膨張係数は,

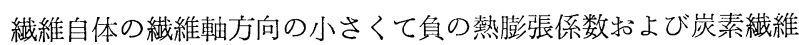

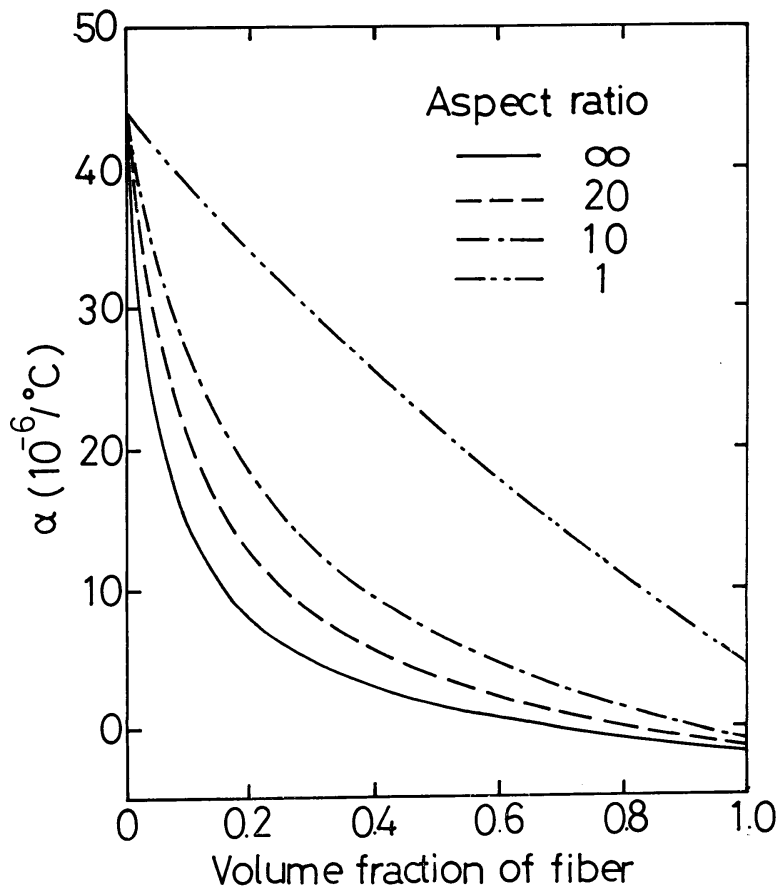

(a)

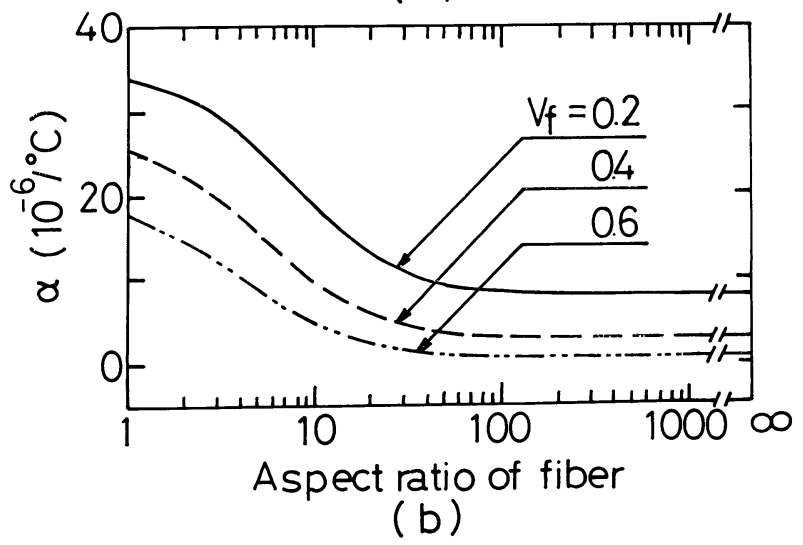

Fig. 6 Thermal expansion coefficient of composite in which carbon fibers are plane-randomly oriented predicted by equivalent inclusion method: (a) as a function of volume fraction of fiber; (b) as a function of aspect ratio of fiber. 

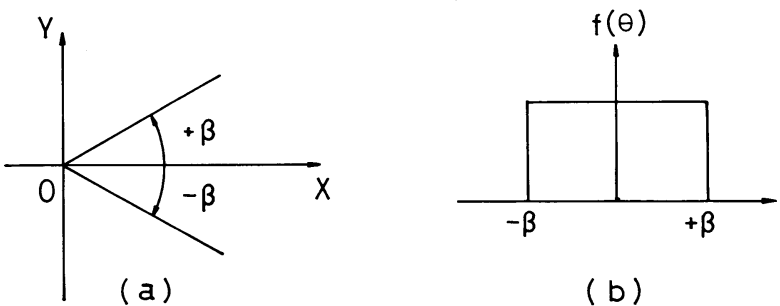

(b)

Fig. 7 (a) Fiber orientation limit angle $\beta$, and (b) the probability of orientation distribution.

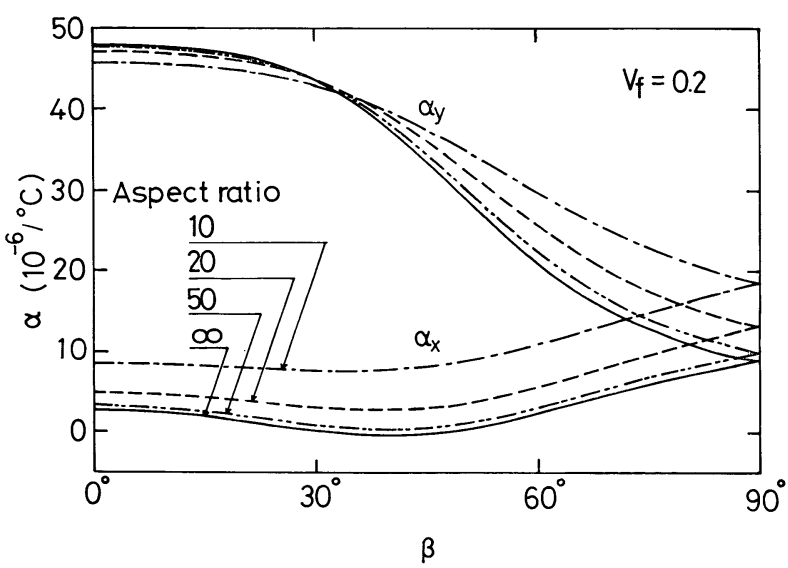

Fig. 8 Thermal expansion coefficient of composite as a function of orientation limit angle $\beta$ calculated by lamination theory.

の熱膨張係数と弾性率の異方性（横等方性）のため， $\beta$ の増加と ともに最初減少してから増加する。 $\beta$ が $30^{\circ}$ 以下の場合, アスぺ クト比が大きいと, 横 $(y)$ 方向の膨張はより大きくなるが， $\beta$ がある臨界值を越えると，アスペクト比の増加とともに低い值を 示す. $\beta=0^{\circ}$ の場合は一軸配向の熱膨張係数と同じで, $\beta=90^{\circ}$ の 場合は Fig. 5 に示した平面ランダム配向と同じになる。積層理 論および等価介在物法から求めた熱膨張係数を $\beta$ の関数として Fig. 9 亿比較する. ここでは繊維のアスペクト比 $\rho=c / a$ (Fig. 1 参照）を100とした， $\alpha_{\mathrm{x}}, \alpha_{\mathrm{y}}$ は $\beta>40^{\circ}$ で積層理論の方が高い 值を示している．この差は，等価介在物法は全ての繊維の間の相 互作用を考慮しているのに対して，積層理論は異なる層の繊維間 の相互作用を無視しているため生じたものと考劣られる. Fig. 9 の $\alpha_{\mathrm{z}}$ は，等価介在物法から求めた值である.

配向分布している複合材の熱膨張係数を等価介在物法から予測 する様々の理論では，䋐維を等方性と仮定し，炭素繊維複合材に は言及していない，これは炭素纎維の大きな異方性のため，Fig. 6 のような結果が生ずるためと考兄られ。，そこで，まず理論的 にはなんら矛盾を生じない等方性のガラス緘維について，積層理 論と等価介在物法から複合材の熱膨張係数を予測しそれらを比較 する．Fig. 10 は等方性のガラス纎維が平面ランダム配向してい る場合の計算結果である. 積層理論による熱膨張係数（実線 : $\alpha_{\mathrm{L}}^{\mathrm{P}}$ ) と等価介在物法による熱膨張係数（破線： $\alpha_{\mathrm{E}}^{\mathrm{P}}$ ) との差は, 体積分率执よびアスペクト比によって異なる。 その差 $\left(\alpha_{\mathrm{L}}^{\mathrm{P}}-\right.$ $\left.\alpha_{\mathrm{E}}^{\mathrm{P}}\right)$ を瀻維の体積分率の関数として Fig. 11 亿比較した. Fig. 11 でガラス複合材の場合（実線），体積分率60\%付近に最大值を もつが，炭素緎維複合材の場合（破線）はほぼ直線的に増加して

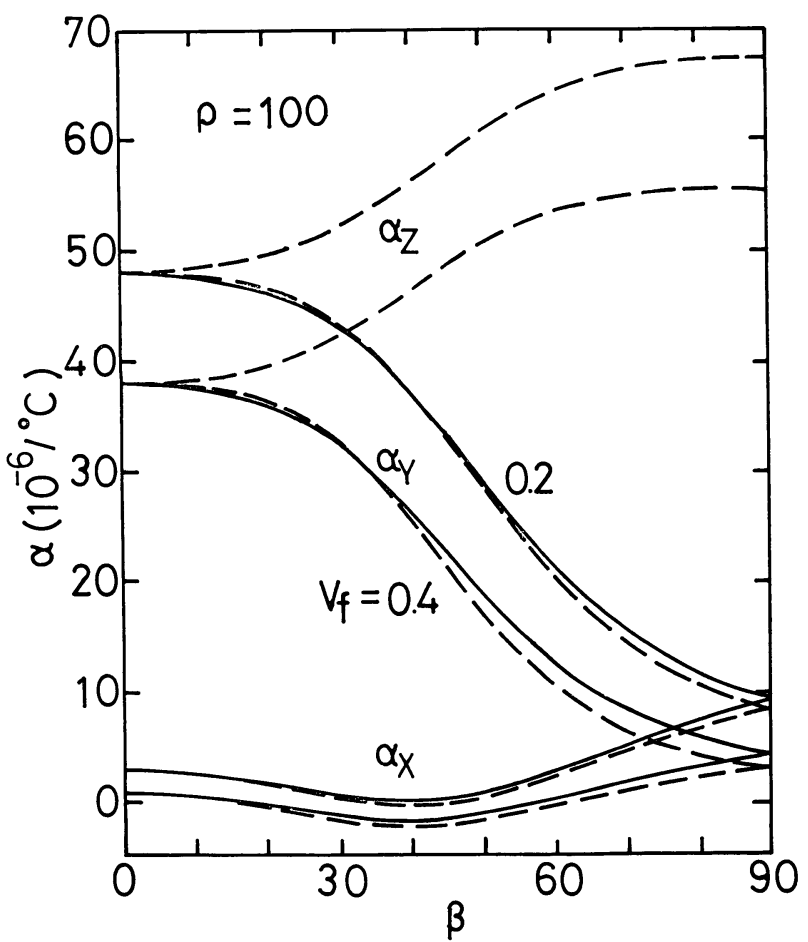

Fig. 9 Thermal expansion coefficient of composite reinforced with carbon fiber of aspect ratio $\rho=100$ as a function of orientation limit angle $\beta$. _ : Lamination theory, ---- : equivalent inclusion method.

いる. しかし，その差は $V_{\mathrm{f}}=80 \%$ 程度まで炭素繊維複合材の方 が小さい.

すなわち，一方向繊維複合材を積層した複合材と，同一層中の 纎維が配向分布をもつ複合材との差は，ガラス複合材について Fig. 10 によって与えられる. これに対して炭素紻維複合材の場 合, 等価介在物法と理論的に矛盾を含まない積層理論による予測 值との差 (Fig. 5 と 6 及び Fig. 9) は，ガラスの場合と比べて 小さく，熱膨張係数を測定するときの誤差を考虑すると，この差 は無視できる。したがって，繊維体積分率が小さい範囲（例えば, Fig. 9 の20，40\%) では，炭素緘維が同一層中で配向分布をもつ

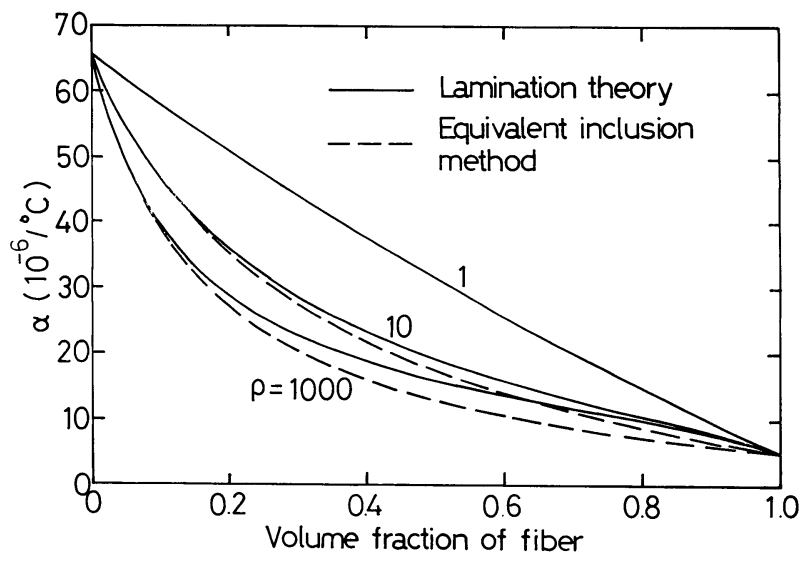

Fig. 10 Thermal expansion coefficient of a glass fiber/epoxy composite as a function of volume fraction of glass fiber. 


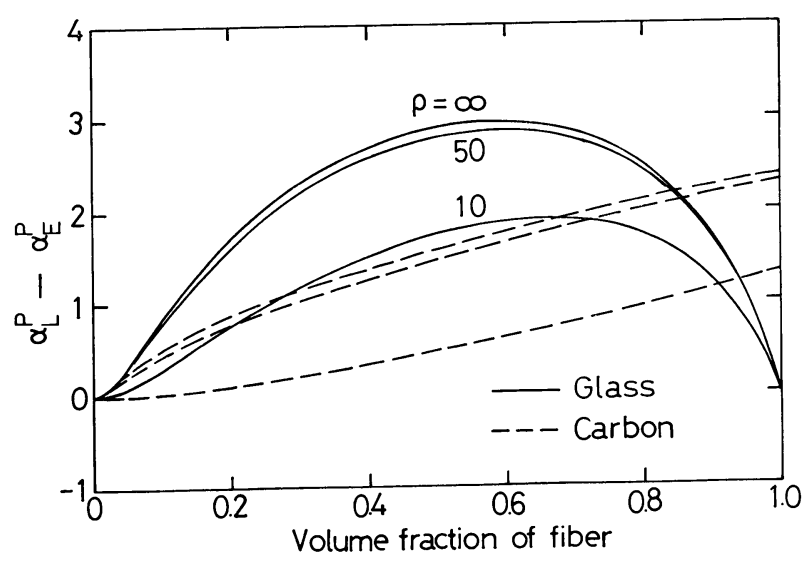

Fig. 11 Difference between the thermal expansion coefficients of the composites reinforced with plane-randomly oriented fibers predicted by lamination theory $\left(\alpha_{\mathrm{L}}^{\mathrm{P}}\right)$ and by equivalent inclusion method $\left(\alpha_{\mathrm{E}^{\mathrm{P}}}\right)$ as a function of volume fraction of fiber.

複合材料の熱膨張係数は, 実用的には積層理論なたは等価介在物 法によって近似できるといえる。

\section{4. 結 論}

本報告では，任意のアスペクト比をもつ強化繊維が配向分布し ている䋐維複合材料について，等価介在物法による熱膨張係数解 析法を一般的に定式化し，積層理論による予測上比較検討した.

積層理論 ${ }^{13), 14}$ は，単層板の性質から積層板の性質を予測する ために有效であり，等価介在物法3 ${ }^{3)}$ ) は䋐維とマトリックスの性 質から複合材料の性質を予測するために有効である。したがって, 一方向繊維複合材 (単層板) の熱膨張係数5) と弾性率 ${ }^{17}$ )を等価介 在物法によって予測し (Fig. 2)，それを種々の方向に積層した積 層複合材料の熱膨張係数は積層理論によって予測できる (Fig. 3).すなわち，積層理論は䋐維の配向分布を一方向繊維複合材 (単層板) の配向分布で近似するものである. 一方，等価介在物 法は同一層中の繊維が配向分布をもつ場合にも適用できる (Fig. 10)．ただし，炭素絨維のよ5に大きな異方性をるつ繊維が配向 分布している場合には，紻維体積分率が大きくなると矛盾が生ず る (Fig. 6).

積層理論と等価介在物法による熱膨張係数予測值の差 $\left(\alpha_{\mathrm{L}}^{\mathrm{P}}-\right.$ $\left.\alpha_{\mathrm{E}}^{\mathrm{P}}\right)$ は, 配向の異なる繊維間の相互作用によるものである。こ の差は, 理論的に正しい予測を与える等方性のガラス絨維の場合 (Fig. 10, Fig. 11 実線) と比べて, 瀻維体積分率 $80 \%$ 以下では 炭素繊維複合材 (Fig. 11 破線) の方が小さい. したがって, 繊 維体積分率が小さい場合（例光ば，Fig. 9 亿示した $V_{\mathrm{f}}=0.2,0.4$ の場合), 積層理論と等価介在物法との差は比較的小さく, 熱膨 張係数の測定精度を考虑すると, 積層理論, 等価介在物法ともに 十分実用的な予測を与えるるのと考穴られる。

\section{文献}

1) 村山和永, 田中豊喜, 材料, 25，417（1976）.

2) Ishikawa, T., and H. Fukunaga, "Proceedings of the Third Japan-U.S. Conference on Composite Materials", Tokyo, p. 701 (1986).
3) Eshelby, J.D., Proc. Roy. Soc., London, A241, 376 (1957).

4) Takahashi, K., K. Harakawa, and T. Sakai, J. Compos. Mater., 14(supplement), 144 (1980).

5）京野哲幸, 高橋清久, 材料, 38，307 (1989).

6) Takao, Y., Report of Research Institute for Applied Mechanics, Kyushu Univ., Vol. 31, No. 97, 15 (1983).

7) Ishikawa, T., K. Kojima, and S. Kobayashi, J. Compos. Mater., 12, 153 (1978).

8) Takao, Y., and M. Taya, J. Appl. Mech., 52, 806 (1985).

9) Takao, Y., and M. Taya, J. Compos. Mater., 21, 140 (1987).

10) Craft, W.J., and R.M. Christensen, J. Compos. Mater., 15, 2 (1980).

11) Uemura, M., H. Iyama, and Y. Yamaguchi, J. Thermal Stresses, 2, 393 (1979).

12) Takao, Y., private communication.

13) Jones, R.M., "Mechanics of Composite Materials" (1975), McGraw-Hill, New York, Chap. 2.

14) Mallick, P.K., "Fiber-Reinforced Composites" (1988), Dekker, New York \& Basel, Chap. 3.

15) Bowles, D.E., and S.S. Tompkins, J. Compos. Mater., 23, 370 (1989).

16) Fahmy, A.A., and A.N. Ragai, J. Appl. Phys., 41, 5112 (1970).

17）高橋清久, 原川和久, 伴菊夫, 酒井哲也, 繊維学会誌, 39, 349 (1983).

\section{付録 Eshelby のテンソル}

ここでは, Eshelby のテンソルを 6 行 6 列で表示する. Fig. 1 (a) のように充填材を回転棈円体,

$$
\frac{\grave{x}_{1}^{2}}{a^{2}}+\frac{\grave{x}_{2}^{2}}{a^{2}}+\frac{\dot{x}_{3}^{2}}{c^{2}} \leqq 1
$$

とすると, Eshelby のテンソル $T_{\mathrm{ij}}$ は次式で与えられる。ただし， $\rho$ は棈円体のアスペクト比 $(\rho=c / a), \nu$ はマリックスのポア ソン比を表す.

$$
\begin{aligned}
T_{11}=T_{22}= & \left\{\left[-4(1-2 \nu) \rho^{2}+13-8 \nu\right] K\right. \\
& \left.+(10-8 \nu) \rho^{4}-(19-8 \nu) \rho^{2}\right\} / M \\
T_{33}=8\left\{\left[2(2-\nu) \rho^{2}-1+2 \nu\right] K\right. & \\
& \left.-(5-2 \nu) \rho^{2}+2(1-\nu)\right\} / M \\
T_{12}= & T_{21}=\left\{\left[4(1-2 \nu) \rho^{2}-1+8 \nu\right] K\right. \\
& \left.-(2-8 \nu) \rho^{4}-(1+8 \nu) \rho^{2}\right\} / M \\
T_{13}= & T_{23}=4\left\{-\left[2(1+\nu) \rho^{2}+1-2 \nu\right] K\right. \\
& \left.+2 \nu \rho^{4}+(3-2 \nu) \rho^{2}\right\} / M \\
T_{31}= & T_{32}=4\left\{-\left[2(1-2 \nu) \rho^{2}+1+4 \nu\right] K\right. \\
& \left.+(3-4 \nu) \rho^{2}+4 \nu\right\} / M \\
T_{44}= & T_{55}=8\left\{-\left[(1+\nu) \rho^{2}+2-\nu\right] K\right. \\
& \left.+(1-\nu) \rho^{4}+3 \nu \rho^{2}+4(1-\nu)\right\} / M \\
T_{66}=2\{- & {\left[4(1-2 \nu) \rho^{2}-7+8 \nu\right] K } \\
& \left.+(6-8 \nu) \rho^{4}-(9-8 \nu) \rho^{2}\right\} / M
\end{aligned}
$$


ここで,

$$
\begin{aligned}
& K=\left[\begin{array}{ll}
\rho \cosh ^{-1} \rho / \sqrt{\rho^{2}-1} & (\rho>1) \\
\rho \cos ^{-1} \rho / \sqrt{1-\rho^{2}} & (\rho<1)
\end{array}\right. \\
& M=16(1-\nu)\left(\rho^{2}-1\right)^{2}
\end{aligned}
$$

である、また，充填材が球 $(a=c)$ の場合には，

$$
T_{11}=T_{22}=T_{33}=\frac{7-5 \nu}{15(1-\nu)}
$$$$
\text { (A.3) } \quad T_{12}=T_{13}=T_{21}=T_{23}=T_{31}=T_{32}=-\frac{1-5 \nu}{15(1-\nu)}
$$$$
\text { (A.4) } \quad T_{44}=T_{55}=T_{66}=\frac{2(4-5 \nu)}{15(1-\nu)}
$$ 